Fall 2009

\title{
Making homework count: Homework as a collective task for language minority families
}

Kathy R. Fox

University of North Carolina

Follow this and additional works at: https://digitalscholarship.unlv.edu/jpme

\section{Repository Citation}

Fox, Kathy R. (2009) "Making homework count: Homework as a collective task for language minority families," Journal of Praxis in Multicultural Education: Vol. 4: No. 1, Article 2.

DOI: 10.9741/2161-2978.1001

Available at: https://digitalscholarship.unlv.edu/jpme/vol4/iss1/2

This Article is protected by copyright and/or related rights. It has been brought to you by Digital Scholarship@UNLV with permission from the rights-holder(s). You are free to use this Article in any way that is permitted by the copyright and related rights legislation that applies to your use. For other uses you need to obtain permission from the rights-holder(s) directly, unless additional rights are indicated by a Creative Commons license in the record and/ or on the work itself.

This Article has been accepted for inclusion in Journal of Praxis in Multicultural Education by an authorized administrator of Digital Scholarship@UNLV. For more information, please contact digitalscholarship@unlv.edu. 


\title{
Making Homework Count: Homework as a Collective Task for Language Minority Families
}

\author{
Kathy R. Fox
}

In response to a writing prompt asking, "What can parents do to ensure academic success for their child?" a mother with three children under the age of six wrote: "In my opinion he needs motivation from his parents and interest in his homework. [He needs] to read a lot so he will have good confidence with his friends and about everything, about his teacher."

This response was typical of those given by participants in a family literacy program (FLP) sponsored by a small urban school district. This program was originally designed to help minority language and culture parents learn functional English in the broader sense, along with strategies to support their children's academic development through parent education focused on school practices. Parents not raised in the United States know there is a mainstream expectation to have a role in motivating and supporting their children's learning, but they often wonder what types of support are expected in an unfamiliar school system (Paratore, Melzi, \& Krol-Sinclair, 1999; Taylor \& Dorsey-Gaines, 1988). Our research found that while parents in this family literacy program had an overwhelming commitment to maintaining family traditions, they also valued learning about mainstream schooling practices, or the mainstream academic discourse practices expected of students to succeed in schools for productivity in society (Gutierrez, 1995; Hicks, 1995). For the participating families, homework and other materials sent home with their children were important resources of school knowledge, as well as valuable sources of English print. Homework served as a mediator between English and Spanish language as the homework was discussed and interpreted in both languages. The daily ritual of unpacking the book bag was a collective practice that included the whole family-the school-age child, siblings, and parents. This ritual was shown to be an acknowledgement of the rich literacy resources a school offers. The contrast of what came to be seen as the collective benefits of homework and other literacy events surrounding school materials with the previously assumed more individualistic benefits of homework and school materials has implications for how teachers and schools view the practice.

Kathy R. Fox is Assistant Professor of Language and Literacy at Watson School of Education at the University of North Carolina, Wilmington. Her interests lie in the riches of learning developed outside of school. She works with students to explore their own background knowledge so that they can better value and acknowledge that of their students.

\section{Review of the Literature}

Families have diverse types of socio-cultural capital, or traditional practices and values, which they in turn bring with them to school. These practices influence their concepts of parent involvement (Gonzalez \& Chrispeels, 2006; Ho, Fox \& Gonzalez, 2007; Hong \& Ho, 2005). Rather than taking a negative or deficit perspective to different types and levels of involvement, a broader approach is necessary. Boethel (2003) suggests that families from racial, ethnic, and cultural minorities are actively involved in their children's schooling, although the involvement may differ in type from that of mainstream majority families. Rosado found, for example, that children of families deemed at risk due to economic and education factors, as well as minority status, practiced a high degree of interaction, though in non-traditional and non-school-based literacy events. These included playing board games, reading mail together, and discussing printing television schedules (1994).

Literature in the study of homework consistently states that best practices for homework include some degree of parent involvement. However, this involvement may mean different things to different people. In many cases, parental involvement in homework is characterized as supervisory, e.g. to establish clear expectations and clear consequences (Beaulieu, et al., 2004; Cooper, 1989). The intent of homework is to help children become independent learners in charge of their own learning, including organization and time management skills (Spalding, 9-13). Stevenson, Chen, and Uttal (1990), however, found that minority culture and language parents, compared to those in the mainstream, perceived homework as a means of improving children's education and thus put more of an academic, rather than character or social, significance on it.

Much of the literature addressed to parents and teachers characterizes homework as a potentially traumatic event, i.e. as a hassle (Beaulieu \& Granzin, 2004) or as causing emotional distress as in Homework without Tears (Canter, et al., 1988). Perhaps to reinforce the seriousness of the event, the optimal environment of the homework 
activity is consistently recommended to be "a quiet place, away from distractions, with ample room to work" (Spalding, 2004, 1).

The program described here viewed parents from the perspective of knowledgeable tutors and teachers for their children. A conscious additive, rather than deficit, approach was taken to the design of the program, ensuring that parents and families were seen as whole, rather than needing to be fixed. As in Boettel's work highlighting findings that families from minority language and cultural backgrounds are actively involved in their children's schooling, this study makes visible linguistic and cultural practices that families have in place where literacy and learning are concerned. This existing "funds of knowledge" perspective (Moll, Amanti, Neff, \& González, 1992) led to a focus on school and family homework practices as a way to inform teachers and program administrators about the pre-existing practices in the homes.

\section{Method}

\section{The Two Phases of the Study: Homework Lab and Home}

The focus of this study was two-fold. First, a detailed examination of the FLP homework lab (Phase One) was conducted. Specifically, Phase One addressed the question: How did the FLP support parents in helping their children with schoolwork through practices in a homework lab? Phase Two, on the other hand, focused on homework as practiced in the homes of seven FLP families who volunteered to participate in home visits, which included observations and interviews. Phase Two addressed the question: What homework practices did parents employ in the home to support their children with their schoolwork?

An ethnographic perspective was employed in approaching this study using both quantitative and qualitative data to push further in the inquiry. From this approach, each step of the analysis results in subsequent questions, which are generated through interacting with the data and the initial findings and shapes the next step of the data collection, analysis, and subsequent investigation (Zaharlick \& Green, 1991). The theoretical perspective of social constructionism was taken, dealing with knowledge formation and processes between participants in social situations (Green \& Bloom, 1997). This approach can be contrasted with "constructivism," which is primarily concerned with the influence of social processes upon an individual's psychological construction of meaning (Hruby, 2001). An important component of this approach is the view that knowledge and actions are not "owned" by an individual, but instead are the product of the social interactions and events of a particular social group. Cultural knowledge is collective, rather than individual. The interactional norms of the underlying structure of a community and/or group is made known as the researcher captures the ordinary aspects of life, in order to identify the extraordinary, or marked, aspects of life (Green \& Meyer, 1991). This study then attempts to make visible what literacy practices are practiced by participants in the school-based family literacy program and home.

\section{Phase One: The School-Based Family Literacy Class}

The participants in the initial study were language minority families enrolled in a family literacy program aimed at teaching English to Spanish-speaking parents. The program included 50 FLP participants (four males and 46 females for each year), 32 of who were present at the beginning and end of the two academic years. The participants were recruited via school flyers, other community advertisements, and teacher recommendations. With one exception, all participants were Latino, born in Latin America, and spoke Spanish as a first language.

Classes were designed and implemented to meet the needs of both parents and children. Although this article reports primarily on the qualitative results of the study, seven quantitative assessments were given to determine the literacy skills of the parents in both English and Spanish, the sense of school membership, and cultural involvement. The results of these assessments were used to determine the selection of reading materials for the adult literacy component of the class. Demographic information was also gathered, including age, number of children in the home, employment status, and number of years in the United States. Appendix A includes a brief description of each measure. Interviews regarding goals for the program were conducted at the school site, both individually and in focus groups, with questions distributed prior to the sessions. Parents and teachers were interviewed separately with the interviews occurring either at the school site or in the home. Family literacy classroom observations were conducted at both school sites. Video recordings, still shots, and field notes were used to record data. In total, during two years of program organization and implementation, field notes, videotape, audiotape, and still photographs were collected on 232 occasions at the two schools. Six teacher interviews and nine home visits were conducted. (See Appendix B for a view of the data collection schedule.) 
One obvious programmatic difference was noted between the two schools used in Phase One of the study. One school included a site based homework lab for children and their parents as a means to teach English within the context of family literacy. Parents and children worked together on the school-age child's homework during the first 30 minutes of the class. This difference can be compared to that of the other school in the study where homework was completed in a separate room with childcare workers in the supervisory role, which more closely resembles those described in surveys of other family literacy programs (Paratore, et al., 1999; Rodriguez-Brown \& Meehan, 1998; Sticht, 1970). In these programs children were often encouraged to stay at home with care providers while parents attended adult-oriented family literacy classes in the evening. Because of the uniqueness of this one program, with the emphasis put on homework as a means for acquiring English across the family unit, the program at this one site became the subsequent focus for the evolving examination of home literacy practices.

\section{Phase Two: The Home Setting}

Participants. In the school examined in the next phase of the study, 92\% of the student population of 438 was identified as Hispanic. Demographic data (interviews of participants by a Spanish-speaking research assistant and written survey) revealed that, for the most part, all participating parents had attended at least some schooling in Mexico, with an average of 7.8 years for females and 6 years for males. The average age of participants was 32.4 years (range 25-62 years). Surprisingly, the average time living in the United States was 7.8 years (ranging from .2521 years); that is, rather than attracting newcomers to the United States, this program seemed to draw more established residents. This may have been because these participants had been in the U.S. long enough to know how to enter and enroll in a class of this type; in other words, they knew how to "navigate" the system. In all of the homes at least one parent was employed, and several parents were employed at two or more jobs. Table 1 gives specific data for the seven participant families that participated in Phase Two of the study. This data was gathered from interviews conducted in Spanish with the parents. School data describing the child's attendance and at-risk status was noted from the cumulative file, including report cards and written referrals. The Literate Behavior Logs (see Appendix A) were analyzed for those events most frequently used in the home as literacy activities.

Structure of home visits. Phase Two of the investigation set out to determine, through home visits, what the participant families demonstrated as their own "best practices" as they engaged in homework and literacy activities in the home.

Home visits were seen as a way to support a mutual sense of trust and build a stronger relationship between the home and the school program (Worthy \& Hoffman, 2001). Home visits can be a "gateway" for strengthening communication by making sure that families know that they are cared about outside of the classroom. They can reveal a family's special interests and hobbies. Discourse patterns and literacy practices not brought out in a classroom setting can be made visible (North Central Regional Educational Laboratory, 1994).

Parents were informed about possible home visits in a classroom presentation. The purpose of the home visits was described as providing participants with the opportunity to share what they would like teachers and the research team to know about the homework and literacy practices they used in their homes. Participants were asked to volunteer to open their homes to the researchers. Sample talking points were shared with the participants emphasizing that the focus would be on what was already occurring in the home. These points were typed and distributed to participants (e.g. What type(s) of homework does your child have? How does the teacher manage the homework; is it daily or given as a packet for the week? Where does your child do his/her homework?).

Table 1

Family Demographics

\begin{tabular}{|l|l|l|l|l|l|l|l|}
\hline Data & A & B & C & D & E & F & G \\
\hline \# in household & 6 & 4 & 4 & 5 & 5 & 4 & 6 \\
\hline Adults & 4 & 2 & 2 & 2 & 2 & 2 & 3 \\
\hline Children & 2 & 2 & 2 & 3 & 3 & 2 & 3 \\
\hline $\begin{array}{l}\text { Years of } \\
\text { schooling } \\
\text { prior to US: } \\
\text { Mother }\end{array}$ & 6 & 9 & 9 & 13 & 6 & 6 & 6 \\
\hline Years of & 9 & 9 & 9 & NA & 6 & 2 & 3 \\
\hline
\end{tabular}




\begin{tabular}{|l|l|l|l|l|l|l|l|}
\hline $\begin{array}{l}\text { schooling } \\
\text { prior to US: } \\
\text { Father }\end{array}$ & 12 & 3 & 7 & 11 & 17 & 7 & 4 \\
\hline $\begin{array}{l}\text { Years in US: } \\
\text { Mother }\end{array}$ & 13 & 3 & 7 & NA & 15 & 12 & $20+$ \\
\hline $\begin{array}{l}\text { Years in US: } \\
\text { Father }\end{array}$ & No & Yes & No & No & Yes & No & Yes \\
\hline $\begin{array}{l}\text { Employed: } \\
\text { Mother }\end{array}$ & Yes & Yes & Yes & Yes & Yes & Yes & Yes \\
\hline Employed: Father & No & No & Yes & No & $\begin{array}{l}\text { A: Yes } \\
\text { B: No }\end{array}$ & Yes & No \\
\hline $\begin{array}{l}\text { Child considered } \\
\text { at risk }\end{array}$ & N A & $6 / 175$ & $3 / 172$ & NA & $\begin{array}{l}3 / 171 \\
4 / 170\end{array}$ & NA & NA \\
\hline $\begin{array}{l}\text { Child's school } \\
\text { attendance }\end{array}$ & $\begin{array}{l}\text { Parental emphasis } \\
\text { on Lit Behavior } \\
\text { log }\end{array}$ & Oral & $\begin{array}{l}\text { Home- } \\
\text { work }\end{array}$ & $\begin{array}{l}\text { Home- } \\
\text { work }\end{array}$ & $\begin{array}{l}\text { Home- } \\
\text { work }\end{array}$ & $\begin{array}{l}\text { Oral } \\
\text { Oral }\end{array}$ & $\begin{array}{l}\text { Home- } \\
\text { work }\end{array}$ \\
\hline
\end{tabular}

Note: Families are coded as A-G. NA represents information not available.

Seven families volunteered for the home visit phase of the study. Participants made appointments according to their own convenience, which was most often when they had returned from work and children were home. A second permission slip was signed at the beginning of each home visit session to reinforce to families that care and respect would be used with collected information. Field notes, audiotape, and still photos were used for home visit data collection. The video camera was purposefully not chosen, as it seemed too intrusive for the home setting. Generally a conversational approach to the interview was taken. In this program, home visits occurred in the afternoon and early evening when children were at home together with their parents. Care was taken to ensure that parents understood that observing the child's homework practices was the goal of the visit. A phone call to confirm the appropriateness and timing of the home visit was made on the morning or early afternoon of the scheduled visit. Researchers entered the home with appreciation gifts. Because candy was often given from Latino families as a teacher appreciation gift, it was seen as a culturally appropriate gift to give participant families. Markers, a composition book, and a package of construction paper were also given to each family. The choice of paper over a book was purposeful because, in all cases, children of multiple ages lived in the homes with differing levels of English and Spanish literacy.

Upon entry to the homes, researchers were welcomed by parents and asked to sit down. Although the homes could often be described as small, there were both communal and private areas in each of them. At each visit the homework was carried out in a communal area with multiple family members present.

Phase Two results were analyzed as individual cases and compiled to discover trends in group findings. A summative group finding will be reported here, with representative samples from different families. To provide anonymity, families were assigned pseudonyms.

\section{Results}

\section{Phase One: The School-Based Family Literacy Class}

The school-based homework lab provided a place for children, parents, and teachers to work on homework together. This portion of the regular family literacy class took up the first $1 / 2$ hour of class. In the two years of classroom ethnography work, it was never skipped, moved, or devalued as a part of the schedule, even when other events occurred (e.g. guest speakers, potluck dinners, testing, computer lab instruction).

Trends emerged in how the families and teachers approached homework. In the lab, homework was shown to be an inclusive rather than an independent practice. The homework was central to the "family table;" families entered the lab together and sat together at the same table each week. Desks represented a sort of "nest." Parents used a hands-on approach as the child unpacked the backpack. They organized papers, helped children gather resources (e.g. dictionaries, globes), and kept up with pencils and other tools. Materials such as erasers, pencils, and markers were shared among the family members. Children discussed the English homework with their parent(s) in 
Spanish. Parents were often observed tracking printed directions with the child to initiate the work. Younger and older siblings worked side by side on homework, while parents attended to both sets of papers.

The youngest siblings crawled around underfoot or sat on the lap of the parent. Instead of being encouraged to leave the younger children at home, as in many after-school and evening classes, the entire family was encouraged to attend. In parent interviews, participants stated that this inclusive attitude made it possible for them to participate in the program. In six participant families, children not yet old enough to attend school attended the family literacy class with their parents and siblings. These children were present and shared the parents' attention. They were cared for and included in the family unit while remaining close to the child doing the homework. Often they were included in the homework activity through collective discussion and/or production of the homework. This occurred in a social, or bonding manner with the parent or school age sibling inviting the younger child to participate by helping to find a particular color of crayon or to listen to the homework discussion. In some cases, the younger child was given an activity to do while the parent assisted with the homework, such as a book to look at or a paper to color. Smaller infants played, rested in a stroller within the family circle or unit, and/or were nursed during the homework session. One example, transcribed from video data, showed how the mother, Ms. Jimenez, emphasized her role in the homework process as she focused on the two school-age children with homework rather than the younger child. The two school-age children sat on either side of their mother around one desk. The youngest child, Danny, approximately 3 years old, sat with the mother's help on top of the desk in the center of the family.

Danny repeated three or more times in a loud voice, "Voy a pintar," (I'm going to paint.) Ms. Jimenez, without looking up, clarified a direction term on the homework page to the school-age child. She underlined it with her finger and pointed to it on the page.

Ms. Jimenez then straightened the second child's papers and found the beginning page. She drew in closer to this child, ignoring Danny's questions and comments, while keeping her hand or arm on him in a steadying manner. Throughout the session Ms. Jimenez continued to help the two school-age children by sounding out direction terms and redirecting attention as needed. Danny stayed in the family circle, either on the desktop, on Ms. Jimenez's lap, or directly underfoot of the desk. He continued to ask for activities as he noticed materials around the room but at the same time viewed himself as a member of the family homework group.

Teachers, too, became comfortable with the inclusive family practices seen in the lab. Younger children were greeted by teachers along with the school-age children and parents. Space was made for them at desks. Strollers and other childcare needs were accommodated. Interviews showed that teachers recognized the value of families working together on homework as a primary benefit of the family literacy class. Teachers reported that teaching parents strategies to help with homework was their priority. In one interview, the teacher compared his goal for participants with that of coaching: "... they can learn the tricks of how to do school things. I look at it like a coach. Lots of people can play soccer, but it's different to be a coach. They can learn coaching skills in this class."

Over the two years of classroom observation, stance of the participants during the homework lab varied only slightly. Table 2 shows stance, location, and role for family members and teachers during the $1 / 2$ hour of the homework lab as a part of the family literacy class schedule. Stance indicates the participants' active physical positioning around the family table. Location refers to the participants' designated space at the family table. Role describes the participants' action, particularly as displayed through discourse and movement.

Table 2

Participant Display in Homework Lab

\begin{tabular}{|l|l|l|l|}
\hline Participant & Stance & Location & Role \\
\hline $\begin{array}{l}\text { Child with } \\
\text { homework }\end{array}$ & $\begin{array}{l}\text { Seated but able to } \\
\text { move to get } \\
\text { materials }\end{array}$ & $\begin{array}{l}\text { Close proximity } \\
\text { to parent at family } \\
\text { table }\end{array}$ & $\begin{array}{l}\text { Active in } \\
\text { homework process }\end{array}$ \\
\hline Child as observer & $\begin{array}{l}\text { Alternately seated } \\
\text { and moving } \\
\text { among family } \\
\text { members }\end{array}$ & $\begin{array}{l}\text { Close proximity } \\
\text { to parent at family } \\
\text { table }\end{array}$ & $\begin{array}{l}\text { Observer in } \\
\text { process, sometimes } \\
\text { verbalizing along } \\
\text { with child regarding } \\
\text { homework }\end{array}$ \\
\hline Parent & $\begin{array}{l}\text { Seated next to } \\
\text { child with } \\
\text { homework }\end{array}$ & At family table & $\begin{array}{l}\text { Alternately } \\
\text { teacher/learner with } \\
\text { homework }\end{array}$ \\
\hline
\end{tabular}




\begin{tabular}{|l|l|l|l|}
\hline Family Literacy & Walking & Among family & Coach \\
Class teacher & Greeting & tables & Reference \\
& Observer & & Resource for \\
& Sometimes & & materials \\
& stopping at tables & & Resource for \\
& to talk with parent & & English \\
\hline
\end{tabular}

In only one of 70 documented classroom visits to the school did a parent sit uninvolved as the child worked independently. In this case, the two siblings worked together on the homework, while the mother sat across the table watching them.

\section{Summary}

Parents and teachers recognized the value of supporting the family in academic support inclusive of all ages of children. English homework became visible as an important tool to assist families in multiple literacy practices. The next step of the project was to examine the ways in which homework was practiced in the homes on the nights that families did not attend the program.

\section{Phase Two: The Home Setting}

Analysis of home visit data indicated that families were even more involved in the collective homework process in the homes than was exhibited in the school-based homework lab. Rules such as "Don't begin your homework until your parents are home" and "The homework is for use by all family members" were stated and/or implied across all the participating families. English homework was used as an important resource for print by Spanish-speaking parents, younger, and older siblings; all found benefits from the use of the school-age child's homework and the shared time with the English materials.

Home visits revealed that homework was carried out in a central location of the home, such as a table in the eating area, another time a sofa, and another time a chair bottom serving as a desk for both the mother and the two children. Parents sat shoulder to shoulder or across a table from their children during the homework practice. In no case was a quiet setting with an individual lamp or desk used, as was previously suggested in school and parenting communication from the family literacy classes and the literature on best practices for homework (Beaulieu et al, 2004; Rosado, 1994; Teft, 2000; Unger, 1991).

Household chores were completed prior to, or set aside during, homework time. As in the homework lab, parents were involved in the homework process; parents handled and wrote on the child's homework. This shared processing of the homework served to instigate the homework and model for the child proper homework completion. The close physical contact between the parent and child around the homework was sometimes used for encouragement and other times for redirection. Similar to the homework lab (as shown in Table 1), the physical stance in the home was close, with all attention focused on the homework and school materials.

Homework began with the unpacking of the book bag, usually initiated by the parent, with other family members looking on. Parents and siblings handled and examined the school materials from the book bag, as they had done in the homework lab. The class work and informational flyers were examined, valued, and shared as school correspondence. For example, Samuel explained the food pyramid from a flyer sent home by his first grade teacher. His younger siblings looked on and then discussed the foods as he passed the flyer to them. They then colored the paper, traced over his lettering, and wrote approximations of their own names on the paper.

Parent statements suggested that they recognized homework as a way for them to learn about mainstream school practices. A striking example was made evident with the Ortega family. Mrs. Ortega discussed how her first grade son had shown her a new way to do subtraction by using a number line, as compared to how she had learned in Mexico using tally marks. Mrs. Ortega went on to say that she would now teach her preschool-age daughter, Rosario, how to subtract using a number line, as done in her son's classroom.

Aside from learning English and mainstream school practices, homework was used as a tool for maintaining academic Spanish. In one case, English spelling words were translated for Spanish spelling practice.

In all cases homework was seen as a collective or multiple family member activity. Parents cited this practice as an intentional homework strategy. Older children were observed routinely helping younger ones with their homework. In one apartment complex, families had started an informal homework club where children of mixed age and gender went to each other's homes to do homework within the family group. During one home visit, a neighborhood girl in $3^{\text {rd }}$ grade was visiting the Ruíz home during homework time. Socorro, a first grader in the 
home, was working on a math page with her mother at the dining table. The older girl asked if she could help Socorro with the homework and then, in what language she preferred the assistance. Socorro's mother looked on, smiled, and interacted with the two as they did the remainder of the homework page. The three continued to discuss the math problems, which centered on telling time, in Spanish, as Socorro wrote the answers in English.

\section{Conclusion}

In this study, the school served as a resource for social networking for these language minority families. Families, who might otherwise have been isolated from the mainstream and each other, found in the family literacy class a space for negotiating mainstream schooling practices within a safe environment. The opportunity to be together as members of a group experiencing mainstream practices collectively made the learning experience a positive one. The unpacking of the book bag each day, whether at home or in the homework lab, made accessible social opportunities, such as after school sports and clubs, as well as mainstream information, such as the nutrition chart shared by the first grader.

Homework was used as a multipurpose tool, providing a resource of mainstream academic discourse for language minority families. The printed homework page, as well as English language books and games, provided families with activities that crossed lines of language, gender, age, and literacy level. In some instances the schoolage child was the knower or negotiator for family members, including younger siblings and parents. Homework also provided a space for the parents to use academic language in the translation and negotiation of working through the homework in Spanish. In these instances, the parent was the knower, ensuring that the concept being taught in the homework was truly understood in the child's native language.

The language and practice of homework in the home differed from what is reported in the literature as best practices for homework achievement (Beaulieu et al 2004; Canter, et al 1988; Spalding, 2004; Unger, 1991). The academic goals of homework practices as demonstrated in the home visits contrasted with recommended best practices in that they emphasized family-oriented goals and social relationships more than an individual's growth in independence. Family members used the child's homework with the intent to learn mainstream academic practices, including English. The homework was used as a print source for literacy, including native language discourse. The focus changed from individual achievement to a bi-directional reciprocal relationship between the parents, the children, and the homework. The setting differed from the recommended quiet, well-lit area to a central location in the family home. Resources were shown to include social and academic discourse between family members and others, in contrast to only textbooks and reference materials.

The home visits revealed that in the homes, as in the family literacy program classes, homework was a family focus, with multiple goals and communicative benefits, rather than an individual event. Rather than seeing homework as a source of tears, homework offered quality time for all family members. These results may have important implications for classroom teachers as they interact with families to improve student success. Best practices should be inclusive, making sure that what counts in one setting is acknowledged by another. Just as homework is traditionally thought of as a way to practice school concepts for the school-age child, here, homework conveyed mainstream schooling practices to multiple family members. Rather than thinking of homework and school materials as individual, in the case of these families, the book bag held potential for collective benefits for multiple family members.

\section{References}

Bakhtin, M. (1986). Speech genres and other late essays. Trans. Vern W. McGee. Ed. Caryl Emerson and Michael Holquist. University of Texas Press Slavic Series 8. 1979 (Russian). Austin: University of Texas Press, 1986. 60-102.

Beaulieu, J. \& Granzin, A. (2004). Taking the hassle out of homework: How to make homework a more positive experience for your child. Our Children Magazine, 25 (2). 9-13.

California Department of Education (2004). Current and Historical Levels of Implementation in the CommunityBased English Tutoring Program. FY 1998 to 2002 Survey Results

California Tomorrow (1998). Update on Proposition 227. California Association for Bilingual Education Newsletter, 21 (6). 3.

Canter, L., Hausner, L. and MacMahon, B. (1988). Homework without tears: A parent's guide for motivating children to do homework and to succeed in school. HarperCollins. 
Census 2000 Data for the State of California (2002). Retrieved 1/2/2002, from http://www.census.gov/census 2000/states/ca.html.

Disney (1998). Disney's Mulan classic storybook. Adapted from the movie by Lisa Ann Marsoli. Disney Press.

Fox, K. (2003). Dissertation. Instruction of Mainstream Academic Discourse in a Family Literacy Project: The Effects of California's Proposition 227 Legislation on a Parent-School Population. University of California, Santa Barbara.

Goodenow, (1997). Psychological sense of school membership. Department of Education. Tufts University, Medford, MA.

Green, J. \& Bloom, D. (1997). Ethnography and ethnographers of and in education: A situated perspective. In S.B. Heath, J. Flood \& D. Lapp (Eds.), Handbook for Research on Teaching in the Communicative and Visual Arts. New York: Macmillan.

Green, J. \& Dixon, C. (1993). Talking knowledge into being: Discursive and social practices in classrooms. Linguistics and Education, 5. 231-239.

Green, J. \& Meyer, L. (1991). The embeddedness of reading in classroom life. In C. Baker and A. Luke (Eds). Towards a Critical Sociology of Reading Pedagogy. Philadelphia: John Benjamin.

Gutierrez, Kris D. (1995). Unpacking academic discourse. Discourse Processes. 22, $28,34$.

Hicks, D. (1995). Discourse learning and teaching. Review of Research in Education. Washington, D.C.: AERA. 49-95.

Ho, H.-Z., Fox, K. \& Gonzalez, M. (2007). Making schools family-friendly. Promising Practices for Teachers to Engage Families of English Language Learners. Editor Dianna Hiatt-Michaels, Editor. Pepperdine University.

Hruby, G. (2001). Sociological, postmodern, and new realism perspectives in social constructionism: Implications for literacy research. Reading Research Quarterly, 36, 1. 48-63.

Jimerson, S. (1997). Oral J. http://www.education.ucsb.edu/jimerson/ orallej.html.

Moll, L., Amanti, C., Neff, D., \& González, N. (1992). Funds of knowledge for teaching: Using a qualitative approach to connect homes and classrooms. Theory Into Practice,31,132-141.

Moll, L. \& Greenberg, J.B. (1990). Creating zones of possibilities: Combining social contexts for instruction. L.C. Moll (Ed.), Vygotsky and Education Instructional Implications and Applications of Sociohistorical Psychology. 319-358.

Paratore, J. R., Melzi, G. and Kroll-Sinclair, B. (1999). What should we expect of family literacy?: Experiences of Latino children whose parents participate in an intergenerational literacy project. International Reading Association.

Rodríguez-Brown, F.V. \& Meehan, M. (1998). Family literacy and adult education: Project FLAME. In C. Smith (Ed.), Literacy for the $21^{\text {st }}$ Century. Westport, CT: Praeger.

Rosado, L. (1994). Promoting partnerships with minority parents: A revolution in today's school restructuring efforts. The Journal of Educational Issues of Language Minority Students, 14.

Santa Barbara County Education Office, (2002). CBEDS Information. Retrieved 1/2/2002, from http:// www.sbceo.k12.ca.us/schools/Welcome.html.

Spalding, C. (2004). Homework tips. WWW.homeworktips.about.com.

Stevenson, H.W., Chen, C. and Uttal, D.H. (1990). Beliefs and achievements: A study of black, white and Hispanic children. Child Development, 61. 508-523.

Sticht, T. (1992). The intergenerational transfer of cognitive skills. In T. G. Sticht, M.J. Beeler, \& B.A. McDonald (Eds.), The Intergenerational Transfer of Cognitive Skills: Volume 1: Programs, Policy and Research Issues. Norwood, NJ: Ablex.

Taylor, D. \& Dorsey-Gaines, C. (1988). Growing up literate: Learning from inner-city families. Portsmouth, NH: Heinemann.

Teft, L. (2000). Excluded voices: Class, culture and family literacy in Scotland. Journal of Adolescent and Adult literacy, 44 (2).

Unger, H. (1991). "What did you learn in school today?" A parent's guide for evaluating your child's school. New York: Facts on File.

Unz, R. \& Tuchman, G. M. (1997). The initiative: English language education for children in public schools.

Worthy, J. \& Hoffman, J.V. (2001). Critical questions: Home visits, reading engagement, and farewell. The Reading Teacher, 54 (5).

Zaharlick, A. \& Green, J. (1991). Ethnographic research. In J. Flood, J. Jensen, D. Lapp, \& J. Squire (Eds.), Handbook of Research on Teaching the English Language Arts. New York: Macmillan. 


\section{Appendix A}

\section{Description of Data Measures}

1. Background Information Interview: The testing session began with an interview consisting of 15 questions regarding personal information about the participant and her/his family. Results were used to construct demographic information.

2. School Involvement Survey: Designed by the project researchers and based on standardized surveys, this measure consisted of 25 questions assessing in adult participation in school-related activities both at home and school. The researcher read the questions aloud in Spanish and recorded the answers using a lickert scale.

3. Bicultural Inventory Questionnaire: This is a standardized measure of acculturation and includes questions pertaining to how comfortable the participant feels using her/his first and second language in specific environments. The researcher read the questions aloud in Spanish and recorded the answers using a lickert scale.

4. Psychological Sense of School Membership Survey: This measure was derived from a standardized instrument originally designed for adolescents, and modified to assess an adult's perceived belonging at her/his child's school. It consisted of 16 questions. The researcher read the questions aloud in Spanish and recorded the answers using a lickert scale.

5. Oral J: This measure is an oral test administered by a researcher to each adult individually. It uses three components to measure reading fluency in English: number of letters correctly read in one minute, number of sounds correctly pronounced in one minute, the average number of words read correctly in one minute from three passages.

6. English Structures Test: Designed by the university research team to assess participant's knowledge of grammatical structures, the test consisted of 28 questions. Participants marked their answers using a bubble-in format.

7. Literate Behavior Log: Designed by the university research team, these checklists listed cooperative literacy activities and parent-child monitoring activities that occur in mainstream homes, based on review of research literature. Open spaces were left for parents to fill in their own literate practices, or those not suggested by mainstream literature. These were distributed weekly, and parents turned them into family literacy program teachers during class. 


\section{Appendix B}

Data Collection Schedule

\begin{tabular}{|l|c|l|l|l|l|l|l|l|l|l|l|l|}
\hline \multicolumn{1}{|c|}{ Year 1 } & Aug & Sep & Oct & Nov & Dec & Jan & Feb & Mar & Apr & May & Jun & Jul \\
\hline Team Mtgs & 2 & 3 & 3 & 4 & 2 & 2 & 4 & 3 & 3 & 3 & 2 & 3 \\
\hline Pre-tests & & & 5 & 1 & & & & & & & & \\
\hline Classroom & & & 18 & 15 & 3 & 10 & 11 & 9 & 10 & 8 & & \\
\hline Focus group & & & & & & & & & & 1 & 1 & \\
\hline Year 2 & Aug & Sep & Oct & Nov & Dec & Jan & Feb & Mar & Apr & May & Jun & Jul \\
\hline Team Mtgs & 2 & 2 & 2 & 3 & 2 & 2 & 3 & 3 & 4 & 4 & 2 & 3 \\
\hline Pre-tests & & 6 & 3 & & & & & & & & & \\
\hline Classroom & 4 & 8 & 6 & 6 & 2 & 7 & 5 & 7 & 3 & 5 & & 2 \\
\hline Focus group & & & & & & & 1 & 1 & 1 & 2 & & \\
\hline $\begin{array}{l}\text { Teacher } \\
\text { interviews }\end{array}$ & & & & & & & 1 & 4 & & & 1 & \\
\hline Home visits & & & & & & & & & 9 & & 1 & \\
\hline
\end{tabular}

